\title{
Production of D-lactate from glucose using Klebsiella pneumoniae mutants
}

\author{
Xinjun Feng ${ }^{1,2+} \odot$, Liqun Jiang ${ }^{2 \dagger}$, Xiaojuan Han ${ }^{1}$, Xiutao Liu ${ }^{1,3}$, Zhiqiang Zhao ${ }^{1,3}$, Huizhou Liu ${ }^{1 *}$, Mo Xian ${ }^{1 *}$ \\ and Guang Zhao ${ }^{1 *}$
}

\begin{abstract}
Background: D-Lactate is a valued chemical which can be produced by some bacteria including Klebsiella pneumoniae. However, only a few studies have focused on K. pneumoniae for D-lactate production with a significant amount of by-products, which complicated the purification process and decreased the yield of D-lactate.

Results: Based on the redirection of carbon towards by-product formation, the effects of single-gene and multiplegene deletions in K. pneumoniae on D-lactate production from glucose via acetolactate synthase (budB), acetate kinase ( $a c k A)$, and alcohol dehydrogenase ( $a d h E)$ were tested. Klebsiella pneumoniae mutants had different production behaviours. The accumulation of the main by-products was decreased in the mutants. The triple mutant strain had the most powerful ability to produce optically pure $\mathrm{D}$-lactate from glucose, and was tested with xylose and arabinose as carbon sources. Fed-batch fermentation was also carried out under various aeration rates, and the strain accumulated $125.1 \mathrm{~g} / \mathrm{L}$ D-lactate with a yield of $0.91 \mathrm{~g} / \mathrm{g}$ glucose at $2.5 \mathrm{vvm}$.
\end{abstract}

Conclusions: Knocking out by-product synthesis genes had a remarkable influence on the production and yield of D-lactate. This study demonstrated, for the first time, that $K$. pneumoniae has great potential to convert monosaccharides into D-lactate. The results provide new insights for industrial production of D-lactate by K. pneumoniae.

Keywords: D-Lactate, Acetolactate synthase, Acetate kinase, Alcohol dehydrogenase, Klebsiella pneumoniae

\section{Background}

D-Lactate is an important chiral chemical with widespread applications in herbicides, coatings, adhesive, spices, and cosmetics. D-Lactate is also an excellent monomer for polylactate (PLA) production, a biodegradable plastic. The properties of PLA depend on the monomer composition, and different monomers can be polymerized into different bioplastics, such as poly L-lactate (PLLA), poly D-lactate (PDLA), and poly D, L-lactate (PDLLA). The lower melting point of the traditional homopolymer PLLA restricts its potential applications. Stereocomplex PLA (PDLLA, or sc-PLA), prepared by blending PLLA and PDLA at different ratios, has a

\footnotetext{
*Correspondence: liuhuizhou@qibebt.ac.cn; xianmo@qibebt.ac.cn; xianmo1@qibebt.ac.cn; zhaoguang@qibebt.ac.cn

${ }^{+}$Xinjun Feng and Liqun Jiang contributed equally to this work

${ }^{1}$ CAS Key Laboratory of Biobased Materials, Qingdao Institute

of Bioenergy and Bioprocess Technology, Chinese Academy of Sciences, Qingdao 266101, China

Full list of author information is available at the end of the article
}

melting point of $230{ }^{\circ} \mathrm{C}$, which is $50{ }^{\circ} \mathrm{C}$ higher than that of homopolymers; the mechanical performance and hydrolysis resistance of sc-PLA are also improved [1, 2]. With the continued growth of the PLA global market, there will be a great demand for polymer-grade $\mathrm{D}$-lactate.

Biosynthesis of chemicals has attracted great attention because of its high efficiency, sustainable development, and ability to alleviate dependence on petroleum-based materials. D-Lactate can be produced by fermentation using wild-type microbes, such as Lactobacillus [3], Sporolactobacillus [4] and metabolic engineered strains, including those of the Escherichia [5], Saccharomyces [6], and Klebsiella [7] genera. Blocking the by-products synthesized during metabolic engineering is a primary solution to improve D-lactate production. For example, inactivation of the L-lactate dehydrogenase gene $l d h L 1$ and phosphoketolase genes $x p K 1$ and $x p K 2$ significantly increases D-lactate production [8]. Single-gene deletions of acetate kinase (ackA), phosphoenolpyruvate synthase 
(pps), pyruvate formate lyase ( $p f l B)$, FAD-binding D-lactate dehydrogenase $(d l d)$, pyruvate oxidase (poxB), alcohol dehydrogenase ( $a d h E)$, and fumarate reductase ( $f r d A)$ in Escherichia coli improved the D-lactate yield. After all seven genes were deleted, the resultant strain generated $125 \mathrm{~g} / \mathrm{L}$ D-lactate in a 7-L bioreactor [9].

Klebsiella pneumoniae is a well-studied Gram-negative bacteria that has a high growth rate in minimal medium and is already widely used as a microbial factory for the production of 3-hydroxypropionate [10] and 1,3-propanediol (1,3-PDO) [11]. It also has a wide variety of substrates, including glycerol and monosaccharides (glucose, xylose and arabinose), that can be used to generate biomass and valued chemicals. However, only a few studies have focused on K. pneumoniae for D-lactate production $[12,13]$. The great potential for D-lactate by K. pneumoniae requires further development.

In our previous study [7], engineered $K$. pneumoniae was constructed by overexpressing the D-lactate dehydrogenase gene $l d h A$ with knocking out the 1,3-PDO oxidordeuctase genes $d h a T$ and $y q h D$. The resulting strain produced an extraordinary amount of D-lactate from glycerol under microaerobic conditions in fed-batch fermentation, which was much higher than that of the wild-type strain. And the optical purity is almost 100\%, indicating high enzyme specificity of D-lactate dehydrogenase of $K$. pneumoniae. However, a significant amount of 1,3-PDO was still detected in the broth generated from unclear biosynthesis pathway, which complicated the purification process and decreased the yield of D-lactate.

Klebsiella pneumoniae can also utilize monosaccharides with 2,3-butanediol, D-lactate, ethanol, and acetate as main metabolites. It is speculated that a high yield of D-lactate could also be obtained from glucose with inhibiting the synthesis of by-products. In this study, the effects of single-gene and multiple-gene deletions in $K$. pneumoniae of acetate kinase (ackA), alcohol dehydrogenase $(a d h E)$, and acetolactate synthase $(b u d B)$ were tested for their effects on D-lactate production. The effects of aeration on D-lactate production, metabolic flux and by-products, such as 2,3-butanediol, acetate, ethanol, and succinate, were also investigated. Under 2.5 vvm aeration condition, the triple gene-deficient strain produced $125.1 \mathrm{~g} / \mathrm{L} \mathrm{D}$-lactate in $36 \mathrm{~h}$ with a yield of $0.91 \mathrm{~g} / \mathrm{g}$ glucose.

\section{Methods}

\section{Plasmids, strains, and the construction of plasmids}

The plasmids, strains, and primers used in this study are listed in Table 1. Klebsiella pneumoniae was purchased from American Type Culture Collection (ATCC25955) and used as the parent strain for D-lactate production. Escherichia coli X7213 was used for suicide vector preparation. The genomic DNA of $K$. pneumoniae was extracted using the E.Z.N.A. ${ }^{\circledR}$ Bacterial DNA Kit (Omega Bio-tek, Georgia, America).

All gene fragments were amplified by PCR using the genomic DNA of $K$. pneumoniae as a template. For budB (Genebank ID: 11848061) deletion, approximately 500bp fragments upstream and downstream of this gene were amplified using the up-primers (1448 and 1449) and down-primers (1450 and 1451), respectively. The PCR mixture consisted of $1 \mathrm{ng}$ of genomic DNA, $0.2 \mu \mathrm{mol}$ of primers, $25 \mu \mathrm{L}$ of double-distilled water, and $25 \mu \mathrm{L}$ of PrimeSTAR MAX DNA Polymerase (TaKaRa, Dalian, China). The PCR was carried out at $95{ }^{\circ} \mathrm{C}$ for $5 \mathrm{~min}$, followed by 30 cycles of $95{ }^{\circ} \mathrm{C}$ for $30 \mathrm{~s}, 55^{\circ} \mathrm{C}$ for $30 \mathrm{~s}$, and $72{ }^{\circ} \mathrm{C}$ for $30 \mathrm{~s}$, with a final extension step of $72{ }^{\circ} \mathrm{C}$ for $10 \mathrm{~min}$. Following gel electrophoresis, the PCR products were purified using the E.Z.N.A. ${ }^{\circledR}$ Gel Extraction Kit. After obtained the two fragments, overlapping PCR was carried out to generate a ligated segment, which was cloned into the pRE112 suicide vector after digestion with the restriction enzymes $X b a \mathrm{I}$ and $S a c \mathrm{I}$, resulting in the plasmid pRE112- $\triangle b u d B$. The fragments of ackA (Genebank ID: 11848786) and adhE (Genebank ID: 11848216) were amplified by PCR using the corresponding primers (Table 1), and the same method was used to construct pRE112- $\triangle a c k A$ and pRE112- $\triangle a d h E$. $\triangle a c k A$ was cloned into pRE112 using the same sites, $X b a \mathrm{I}$ and SacI. To generate pRE112- $\triangle a d h E$, the engineered segment was inserted into PRE112 with the restriction sites $X b a \mathrm{I}$ and $K p n \mathrm{I}$.

\section{Construction of the gene-deficient mutants}

To construct gene-deficient mutants, E. coli strain $\chi 7213$, containing the plasmids pRE112- $\triangle b u d B$, pRE112$\triangle a c k A$, or pRE112- $\triangle a d h E$, was used as a donor in conjugation with $K$. pneumoniae. The mutation segments were introduced into K. pneumoniae by allelic exchange using the suicide vector pRE112, and double recombination was performed to obtain the mutants. For the first recombination, wild $K$. pneumoniae was incubated in Luria-Bertani (LB) media overnight with E. coli $\times 7213$ (pRE112- $\Delta b u d B)$, then selected on an LB plate with $30 \mathrm{mg} / \mathrm{L}$ chloramphenicol before verification by PCR with the primers ID-pRE112 and 1384. The correct recombinant was incubated in LB media overnight for the second recombination, then cultured on $10 \%$ sucrose plates for selection and verified by PCR with the primers 1385 and 1386. Genomic DNA was used as a positive control, and the budB mutant was named as Q2699.

The other single gene-deficient mutants, Q2657 and Q2666, were constructed using the method described above. To make the double gene mutants, E. coli strain $X 7213$, which contained another recombinant suicide 
Table 1 Bacterial strains, plasmids, and primers used in this study

\begin{tabular}{|c|c|c|}
\hline Strain, plasmid and primers & Description & Source \\
\hline \multicolumn{3}{|l|}{ Strains } \\
\hline E. coli DH5a & Cloning host & Lab collection \\
\hline E. coli $\times 7213$ & Host strain for pRE112, DAP auxotrophic strain & [14] \\
\hline Q1188 & K. pneumoniae ATCC25955 & ATCC \\
\hline Q2657 & K. pneumoniae ATCC25955 $\triangle a d h E$ & This study \\
\hline Q2666 & K. pneumoniae ATCC25955 $\triangle a c k A$ & This study \\
\hline Q2699 & K. pneumoniae ATCC25955 $\triangle$ budB & This study \\
\hline Q2702 & K. pneumoniae ATCC25955 $\triangle b u d B \triangle a c k A \triangle a d h E$ & This study \\
\hline Q2710 & K. pneumoniae ATCC25955 $\triangle b u d B \triangle a d h E$ & This study \\
\hline Q2743 & K. pneumoniae ATCC25955 $\triangle$ budB $\triangle a c k A$ & This study \\
\hline \multicolumn{3}{|l|}{ Plasmids } \\
\hline pRE112 & Suicide vector, R6k origin, chloramphenicol resistant & [15] \\
\hline pRE112- $\triangle b u d B$ & Suicide vector for construction of $\Delta b u d B$ mutant & This study \\
\hline pRE112- $\triangle a d h E$ & Suicide vector for construction of $\triangle a d h E$ mutant & This study \\
\hline pRE112- $\triangle a c k A$ & Suicide vector for construction of $\triangle a c k A$ mutant & This study \\
\hline Primers & Sequence $\left(5^{\prime}-3^{\prime}\right)$ & Restriction enzymes \\
\hline ID-pRE112 & CAAGGCGACAAGGTGCTGATG & \\
\hline \multicolumn{3}{|l|}{$\triangle a d h E$ construction } \\
\hline 1381 & GCTCTAGAATGGCTGTTACTAATATCGC & $x b a l$ \\
\hline 1382 & CGACGCCGATAGCAGGTTTAC & \\
\hline 1383 & GTAAACCTGCTATCGGCGTCGGTGCGTTCGGTGGTCTGGAT & \\
\hline 1384 & GGGGTACCTCAGCCTTTACCGGAGCAAC & Kpnl \\
\hline 1385 & ATAATGTCGAATCGAGCGAC & \\
\hline 1386 & GCTTGTCGCGATGCTATCGC & \\
\hline \multicolumn{3}{|l|}{$\triangle a c k A$ construction } \\
\hline 1387 & GCTCTAGAATGTCGAGTAAGTTAGTAC & Xbal \\
\hline 1388 & GCGTAGAGATAGGATTCTTC & \\
\hline 1389 & GAAGAATCCTATCTCTACGCGAAGGCCTGGTGATGGGTAC & \\
\hline 1390 & CGAGCTCTTATGCGGTCAGACGGCTGGC & Sacl \\
\hline 1391 & ATCCTGCGCTACGCTAATGAC & \\
\hline 1392 & CCTGCAGCTCGAATTATTGC & \\
\hline \multicolumn{3}{|l|}{$\Delta b u d B$ construction } \\
\hline 1448 & GCTCTAGAGTCAGTCAGCTGGAAGCTC & $x b a l$ \\
\hline 1449 & ATAAGCTTCGCCACCTGGTC & \\
\hline 1450 & GACCAGGTGGCGAAGCTTATCTGCGCATCGTTCGCGCCAT & \\
\hline 1451 & CGAGCTCTTATCGCGATAATCTACCG & Sacl \\
\hline 1452 & ATGGACAAACAGTATCCG & \\
\hline 1453 & ACAGAATCTGACTCAGATG & \\
\hline \multicolumn{3}{|l|}{ RT-qPCR } \\
\hline 16S rRNA_F & AAGCGTTAATCGGAATTAC & \\
\hline 16SrRNA_R & GCTACACCTGGAATTCTA & \\
\hline 16S rRNA_Probe & (FAM)CTCTACAAGACTCTAGCCTGCCAG(Eclipse) & \\
\hline IdhA_F & GAAGCGGTATGTATCTTC & \\
\hline IdhA_R & CAGGGCGATATATTTCAC & \\
\hline IdhA_Probe & (FAM)CTTCAGCTCTTCCAGCACCG(ECLIPSE) & \\
\hline
\end{tabular}

vector, was used as the donor in conjugation with a single gene-deficient mutant and then verified with antibiotics, sucrose, and PCR with the appropriate primers. The same strategy was used to introduce the third recombinant suicide vector into the double gene mutants to obtain the triple mutant strain. 


\section{Media and growth conditions}

Escherichia coli $\mathrm{X} 7213$ was grown at $37{ }^{\circ} \mathrm{C}$ in $\mathrm{LB}$ medium with diaminopimelic acid (DAP) $(50 \mathrm{mg} / \mathrm{mL})$, and $30 \mathrm{mg} / \mathrm{L}$ chloramphenicol was added for suicide vector maintenance. The fermentation medium used in this study contained the following components (per litre): glucose, $20 \mathrm{~g}$; $\mathrm{NH}_{4} \mathrm{Cl}$, 5.4 g; yeast extract, $3 \mathrm{~g}$; $\mathrm{KH}_{2} \mathrm{PO}_{4}$, 2 g; $\mathrm{K}_{2} \mathrm{HPO}_{4}, 1.6 \mathrm{~g}$; citric acid, $0.42 \mathrm{~g} ; \mathrm{MgSO}_{4} \cdot 7 \mathrm{H}_{2} \mathrm{O}$, $0.2 \mathrm{~g}$; and $1 \mathrm{~mL}$ of trace elements stock solution. The trace element solution was composed of $\mathrm{Na}_{2} \mathrm{MoO}_{4} \cdot 2 \mathrm{H}_{2} \mathrm{O}$ $(0.005 \mathrm{~g} / \mathrm{L}), \mathrm{H}_{3} \mathrm{BO}_{3}(0.062 \mathrm{~g} / \mathrm{L}), \mathrm{CuCl}_{2} \cdot 2 \mathrm{H}_{2} \mathrm{O}(0.17 \mathrm{~g} / \mathrm{L})$, $\mathrm{CoCl}_{2} \cdot 6 \mathrm{H}_{2} \mathrm{O}(0.476 \mathrm{~g} / \mathrm{L}), \mathrm{ZnCl}_{2}(0.684 \mathrm{~g} / \mathrm{L}), \mathrm{MnCl}_{2} \cdot 4 \mathrm{H}_{2} \mathrm{O}$ $(2 \mathrm{~g} / \mathrm{L}), \mathrm{FeCl}_{3} \cdot 6 \mathrm{H}_{2} \mathrm{O}(5 \mathrm{~g} / \mathrm{L})$, and concentrated $\mathrm{HCl}$ $(10 \mathrm{~mL} / \mathrm{L})$.

For shake flask cultivation, the strains were cultured in a 250 -mL flask containing $100 \mathrm{~mL}$ of medium at $37^{\circ} \mathrm{C}$ in an orbital incubator shaker at a speed of $180 \mathrm{rpm}$. The samples were withdrawn to determine the cell mass, glucose, D-lactate, and by-products. $25 \% \mathrm{NH}_{3} \cdot \mathrm{H}_{2} \mathrm{O}$ was added to adjust the $\mathrm{pH}$ every $12 \mathrm{~h}$. Glucose was determined by a SBA-40D biosensor analyser (Institute of Biology, Shandong Academy of sciences, China), and an additional $20 \mathrm{~g} / \mathrm{L}$ glucose was added when the initial carbon source was nearly exhausted. All shaking experiments were carried out in triplicate. For analysis of the utilization of different carbon sources, $20 \mathrm{~g} / \mathrm{L}$ xylose, arabinose, or mixed carbon sources containing glucose, xylose, and arabinose (the ratio of 1:1:1) was used instead of glucose.

Fed-batch fermentation was carried out in a Biostat B plus MO5L fermenter (Sartorius Stedim Biotech $\mathrm{GmbH}$, Germany) with a working volume of $3 \mathrm{~L}$. $200 \mathrm{~mL}$ of the seed solution was inoculated into the bioreactor and performed at $37^{\circ} \mathrm{C}$, with an agitation speed of $400 \mathrm{rpm}$. The broth $\mathrm{pH}$ was automatically maintained at 7.0 with ammonia. Sterile air was sparged at 0.5, 1.0, 1.5, and 2.5 vvm for different aeration conditions. After the initial glucose was nearly exhausted, the fed-batch mode was commenced by feeding a solution containing $70 \%(\mathrm{wt} / \mathrm{v})$ glucose. The residue of glucose was controlled between 2 and $10 \mathrm{~g} / \mathrm{L}$ during fermentation. Samples were withdrawn at intervals to determine the glucose residue, cell mass and the concentrations of metabolites.

\section{Real-time quantitative PCR for IdhA transcriptional level analysis}

Total RNA from wild-type and mutant strains was isolated using Bacteria RNA Kit (Omega). The quantity and purity of the RNAs were determined by optical density measurements at 260 and $280 \mathrm{~nm}$, respectively. RNA was reverse transcribed using TransScrip ${ }^{\circledR}$ One-step gDNA removal and cDNA synthesis SuperMix Kit (TransGen Biotech). For each qPCR, $1 \mu \mathrm{L}$ of sample, $10 \mu \mathrm{L}$ of Premix Ex Taq
(Probe qPCR) $(2 \times)($ TaKaRa), $0.4 \mu \mathrm{L}$ of each primer (from a $10 \mu \mathrm{M}$ of working solution, the primers presented in Table 1), and $0.8 \mu \mathrm{L}$ of probe were added and supplemented with water to a final volume of $20 \mu \mathrm{L}$. The real-time quantitative PCR (RT-qPCR) was run on a LightCycler 480 system (Roche Diagnostics) with 16S rRNA as an internal reference. The qPCR program run consisted of a first step at $95{ }^{\circ} \mathrm{C}$ for $30 \mathrm{~s}$ and afterwards 40 cycles alternating between $5 \mathrm{~s}$ at $95{ }^{\circ} \mathrm{C}$ and $30 \mathrm{~s}$ at $60{ }^{\circ} \mathrm{C}$. The samples were quantified by comparative cycle threshold $(\mathrm{Ct})$ method for relative quantification of gene expression [16].

\section{Analytical methods}

Biomass was monitored using a UV visible spectroscopy system (Varian Cary 50 Bio, US) at $650 \mathrm{~nm}$. The measurements were converted to dry cell weight (DCW) based on one unit of $\mathrm{OD}_{650}$ being equivalent to $0.284 \mathrm{~g} \mathrm{DCW} / \mathrm{L}$. The fermentation products of D-lactate, 2,3-BDO, acetate, ethanol, and succinate were detected by HPLC with a refractive index detector (RI-150, Thermo Spectra System, USA) and ion exchange column (Aminex ${ }^{\circledR}$ HPX-87H, $7.8 \times 300 \mathrm{~mm}$, BioRad) at $60{ }^{\circ} \mathrm{C}$ using $5 \mathrm{mM}$ $\mathrm{H}_{2} \mathrm{SO}_{4}$ as the mobile phase, with a flow rate of $0.5 \mathrm{~mL} /$ min. The optical purity of D-lactate was measured using the reported method [17]. The carbon distribution was calculated based on glucose consumption, and that contained in the main metabolites and biomass. The fraction for cell growth was determined with the elemental composition of $\mathrm{C}_{4} \mathrm{H}_{7} \mathrm{O}_{2} \mathrm{~N}$ [18].

\section{Results and discussion}

\section{Effect of gene deletion on cell growth}

To investigate the effects of single-gene deletion or multigene deletions of $b u d B, a c k A$, and $a d h E$ on cell growth, the gene-deficient mutants and wild-type strain were cultured under the same conditions in shake flask (Fig. 1). Obvious inhibition on cell growth was observed after the

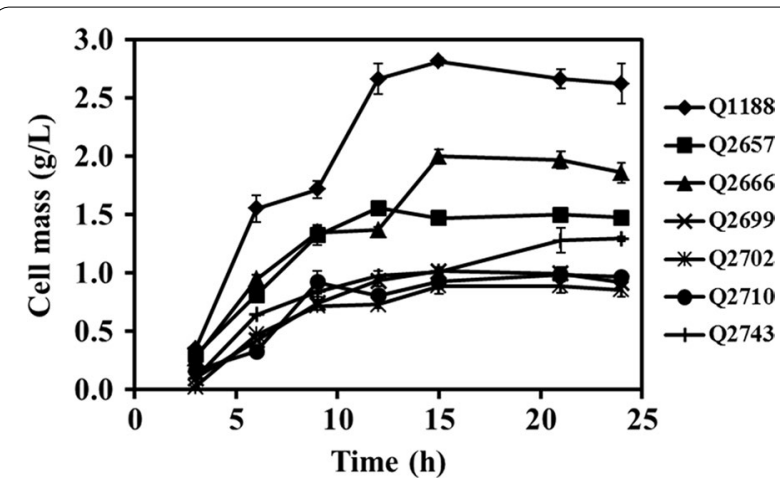

Fig. 1 Growth curves of the parent and mutants of K. pneumoniae with glucose as the carbon source. The experiment was performed in a shaking flask in triplicate, and the standard deviation is shown 
single gene was deleted. In particular, the biomass accumulation of the budB deletion mutant Q2699 was less than half that of the parent strain at $15 \mathrm{~h}$. Growth of the multi-gene knockout strains Q2702, Q2710 and Q2743 was inhibited more severely. The DCW of the triple mutant strain Q2702 was only $0.89 \mathrm{~g} / \mathrm{L}$ in the stationary phase. The results demonstrated that blocking the 2,3BDO pathway significantly reduced cell growth, which is consistent with previous reports [19]. Due to NADH requirements for 2,3-BDO and ethanol formation in $K$. pneumoniae, blocking these by-product pathways could alter the intracellular redox balance, which may act as an inhibitor of cell growth.

\section{Metabolic profiles of single-gene mutants and their effect on D-lactate production}

The production of the main metabolites from glucose by single-gene mutants and wild-type strain was investigated (Fig. 2a). As shown in Fig. 2a, the three mutants had different metabolic performances compared to the wild-type strain. Inactivation of ackA clearly resulted in a reduction in 2,3-BDO and ethanol production. The production of acetate essentially remained the same because complex metabolic pathways of acetate in microbes. A previous report also demonstrated that deleting the primary acetate pathway genes pta-ackA of $K$. pneumoniae had no effect on the formation of acetate [20]. However, in addition to $a c k A$ and $p t a$, there are still many other genes related to acetate secretion. The mutant E. coli with $p t s G$, poxB, $p t a$, and $i c l R$ gene knocked out was confirmed to accumulate only $10 \%$ acetate of the wild strain [21]. It is also proved that acetate excretion is generally caused by an imbalance between the glycolytic pathway and tricarboxylic acid (TCA) cycle. Thus, controlling glucose uptake or enhancing the activity of the TCA cycle might decrease acetate accumulate. Our previous study has revealed that knockout of $\operatorname{arc} A$, a global regulator which repress the TCA cycle, exhibited surprising efficacy in inhibiting acetate synthesis [22]. Theoretically, all the above methods can be used for reducing acetate secretion of K. pneumoniae in future studies. Although acetate accumulation was not inhibited, the ack $A$ mutant strain produced $1.25 \mathrm{~g} / \mathrm{L}$ D-lactate at $24 \mathrm{~h}$ compared to $0.38 \mathrm{~g} / \mathrm{L} \mathrm{D}$-lactate of the wild-type strain.

D-Lactate production reached $4.29 \mathrm{~g} / \mathrm{L}$ at $24 \mathrm{~h}$ for the $\triangle a d h E$ strain Q2657, which was significantly higher than those of the wild-type strain Q1188 and $\triangle a c k A$ strain Q2666. For by-products, Q2657 produced $1.29 \mathrm{~g} / \mathrm{L}$ ethanol and $0.62 \mathrm{~g} / \mathrm{L}$ succinate, which were 72 and $53 \%$ lower than those produced by the wild-type strain, respectively. However, acetate production was improved to $1.85 \mathrm{~g} / \mathrm{L}$. In glucose metabolism of $K$. pneumoniae, glucose is oxidized to pyruvate and then converted into acetyl-CoA; acetyl-CoA can be used for acetate and ethanol production in addition to the TCA cycle. It was speculated that more acetyl-CoA flowed into the acetate pathway after the ethanol pathway was restrained with the $a d h E$ deletion.

Knockout of $b u d B$ resulted in only $0.1 \mathrm{~g} / \mathrm{L} 2,3-\mathrm{BDO}$ production, which confirmed that $\operatorname{budB}$ was the major 2,3-BDO synthesis gene in $K$. pneumoniae. The largest production of D-lactate $(10.1 \mathrm{~g} / \mathrm{L})$ was achieved by the $\triangle b u d B$ strain Q2699, and a yield of 67\% was obtained at $24 \mathrm{~h}$, while those of Q1188, Q2657, and Q2666 were only $0.76,19.54$, and $3.13 \%$, respectively (Fig. 3). These results revealed that deletion of the 2,3-BDO pathway significantly triggered metabolic flux redistribution and generated excess D-lactate production. By contrast, 2,3BDO production was successfully improved by a lactate dehydrogenase-deficient mutant [23]. Additionally, the recombinant strain produced less succinate and ethanol, while acetate production increased to $4.1 \mathrm{~g} / \mathrm{L}$.
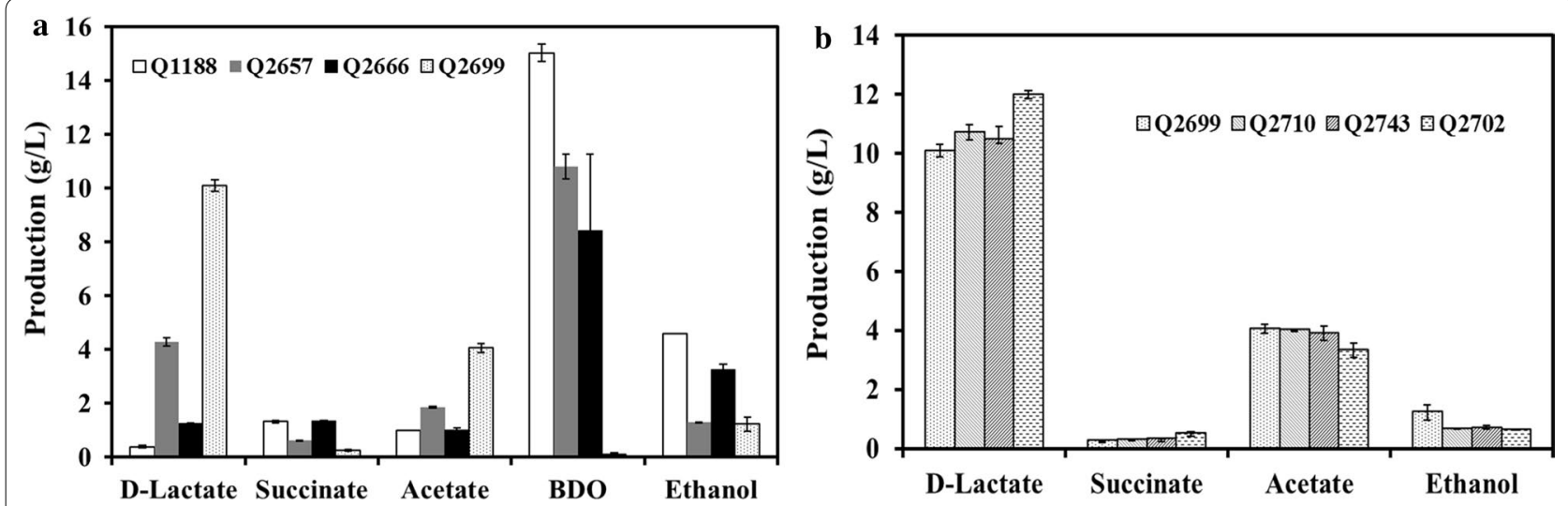

Fig. 2 Metabolite profiles of the parent and mutants of K. pneumoniae. The experiment was performed in a shaking flask in triplicate, and the standard deviation is shown. a Metabolic profiles of single-gene mutants and their effect on D-lactate production. b Metabolic profiles of the multi-gene mutants and their effect on D-lactate production 


\section{Metabolic profiles of the multi-gene mutants and their effect on D-lactate production}

As the $\Delta b u d B$ strain Q2699 obtained the highest production and yield of D-lactate among the single gene mutants, double and triple mutant strains were constructed based on it. As shown in Fig. 2b, the double mutant strains (Q2710 and Q2743) produced slightly more D-lactate than Q2699, and the by-products production was further reduced. However, the D-lactate yields were 56 and 53\%, which were lower than those of Q2699 (Fig. 3). The triple gene-deficient strain exhibited the highest D-lactate synthesis efficiency. Using the $\triangle b u d B \triangle a c k A \triangle a d h E$ strain Q2702, $11.99 \mathrm{~g} / \mathrm{L}$ D-lactate was obtained, which was $19 \%$ higher than that of Q2699, with a yield of 69\%. The production of acetate and ethanol resulted in reductions of 18 and 49\% compared with those of Q2699, respectively. With $b u d B$ deletion, 2,3-BDO was not detected in all of the multi-gene mutants, and the production of succinate remained at a low level.

Formation of the main by-products 2,3-BDO, ethanol, and succinate require $\mathrm{NADH}$, which compete with the D-lactate pathway [24]. More NADH can be used to produce D-lactate after blocking the primary by-products pathway by deleting $b u d B, a c k A$, and $a d h E$. In addition, the transformation of glucose to each mol of 2,3-BDO generates $2 \mathrm{~mol}$ of $\mathrm{CO}_{2}$, which means that more carbon flows into products with blockage of 2,3-BDO synthesis. The routes outlined above may be the primary causes of the higher production and yield of D-lactate achieved by the mutant strains.

\section{Effect of deleting the by-products synthesis genes on the IdhA transcriptional level}

Mutant strains generated increased D-lactate production, and the underlying causes need to be revealed. The total RNAs of the wild-type and mutant strains were extracted, and all of the cDNA samples were diluted to the same

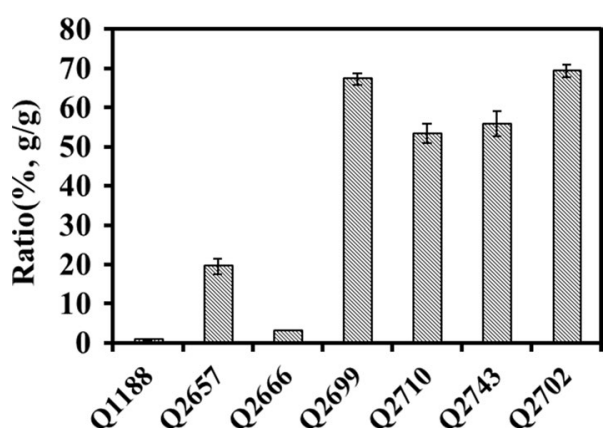

Fig. 3 Conversion ratio of D-lactate production to consumed glucose by the K. pneumoniae parent strain and mutants. The experiment was performed in a shaking flask in triplicate, and the standard deviation is shown

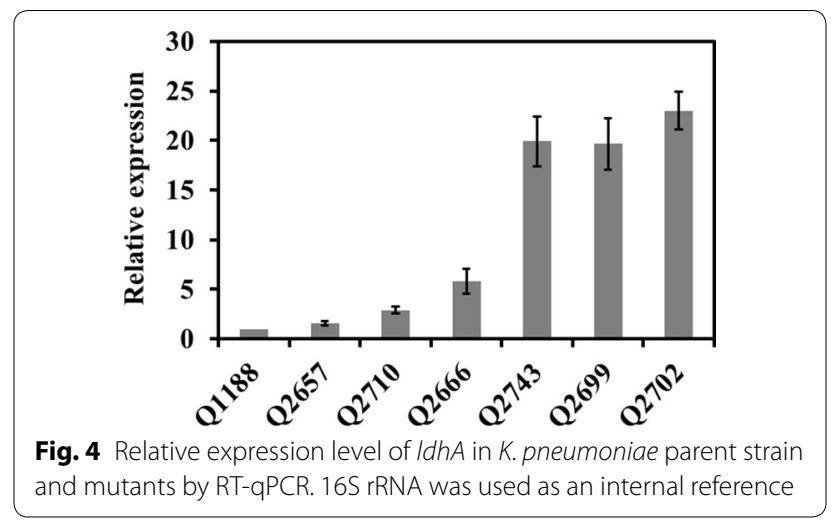

concentration for RT-qPCR. As shown in Fig. 4, the transcriptional levels of the lactate dehydrogenase gene $l d h A$ were higher than those of the wild-type strain in all of the mutant strains, especially Q2699, Q2702 and Q2743 (19.7, 23.0, and 19.9 times of wild-type strain respectively). The results suggested that the deletion of the byproducts synthesis genes up-regulated the transcriptional levels of $l d h A$, which possibly explains the higher D-lactate production by the mutant strains. In previous studies, the specific activity of LDH drastically increased after blocking the 2,3-BDO pathway [25] or with the combined deletion of adhE and ackA-pta [26], which could result in higher D-lactate production. Additionally, blocking the 2,3-BDO pathway affected the metabolic network of $K$. pneumoniae [24]: 511 genes were differentially regulated in the budA deletion mutant compared to the wild type. Many genes related to energy production and coenzyme transport were up-regulated, which may enhance metabolite formation.

Potentiality analysis for carbon source utilization by Q2702 Klebsiella pneumoniae can use a wide spectrum of carbon sources. In addition to glucose, D-xylose and L-arabinose were also tested with Q2702 in this study. As shown in Table 2, each individual sugar and the mixtures were able to be effectively used by the mutant strain Q2702 and generated a similar biomass in flask fermentation. However, the production and yield of D-lactate were significantly decreased when xylose, arabinose, or mixtures of carbon sources were used. For the primary by-products, acetate production decreased and ethanol accumulation enhanced slightly when xylose was used, and succinate production improved when arabinose was used.

In addition, the strain demonstrated a preference for glucose in mixtures of carbon; glucose was exhausted, while a large amount of xylose and arabinose remained at the end of fermentation. Based on the amount of carbon consumed, xylose utilization was slower than arabinose and glucose. Klebsiella oxytoca was also evaluated for 
Table 2 Metabolic profiles of Q2702 using several carbon sources in 24-h-flask cultivation

\begin{tabular}{lccccccc}
\hline Carbon source & D-Lactate (g/L) & Succinate (g/L) & Acetate (g/L) & Ethanol (g/L) & Cell mass (g/L) & $\begin{array}{l}\text { Consumed } \\
\text { carbon }(\mathbf{g} / \mathbf{L})\end{array}$ & $\begin{array}{l}\text { D-Lactate yield } \\
(\mathbf{g} / \mathbf{g})\end{array}$ \\
\hline Glucose & $11.99 \pm 0.14$ & $0.48 \pm 0.08$ & $3.33 \pm 0.24$ & $0.62 \pm 0.01$ & $1.13 \pm 0.09$ & $17.31 \pm 0.22$ & 0.69 \\
D-Xylose & $9.34 \pm 0.21$ & $0.43 \pm 0.02$ & $2.67 \pm 0.14$ & $0.73 \pm 0.13$ & $0.95 \pm 0.11$ & $15.81 \pm 0.25$ & 0.59 \\
L-Arabinose & $8.87 \pm 0.41$ & $0.91 \pm 0.16$ & $3.25 \pm 0.16$ & $0.51 \pm 0.07$ & $1.07 \pm 0.10$ & $16.19 \pm 0.42$ & 0.55 \\
Mixture & $8.36 \pm 0.37$ & $0.41 \pm 0.04$ & $3.11 \pm 0.09$ & $0.57 \pm 0.05$ & $1.08 \pm 0.08$ & $15.57 \pm 0.16$ & 0.54 \\
\hline
\end{tabular}

its ability to ferment mixtures of the sugars L-arabinose, D-xylose and D-glucose (1:1:1); approximately $47 \%$ of xylose was unutilized after $114 \mathrm{~h}$ fermentation, while glucose was exhausted at $24 \mathrm{~h}$ and arabinose was exhausted at $96 \mathrm{~h}$ [27]. As glucose, xylose, and arabinose are the primary components of lignocellulose hydrolysates [28], it is presumed that K. pneumoniae has great potential to ferment lignocellulosic hydrolysates into valued products.

\section{D-Lactate production and metabolic profiles of Q2702} in fed-batch fermentation

As the triple mutant strain Q2702 exhibited the highest capacity for producing D-lactate, fed-batch fermentations were carried out to further enhance production. To investigate the effect of aeration on the production of D-lactate, fed-batch fermentations were conducted at different aeration rates of 0.5, 1.0, 1.5 and 2.5 vvm (Fig. 5). With enhanced aeration, the growth rate and cell mass were improved dramatically at $2.5 \mathrm{vvm}$, which agreed with a previous report $[7,17]$. The maximum cell mass achieved was $5.34 \mathrm{~g} / \mathrm{L}$ at $22 \mathrm{~h}$. The biomass decreased slightly after $24 \mathrm{~h}$ of fermentation, possibly due to cellular toxicity caused by the high lactate concentration.

The aeration conditions significantly impacted D-lactate production. The production was only $80.89 \mathrm{~g} / \mathrm{L}$ at $36 \mathrm{~h}$, with a yield of $0.78 \mathrm{~g} / \mathrm{g}$ glucose under $0.5 \mathrm{vvm}$. With increasing aeration rates, $\mathrm{D}$-lactate production improved to 94.6 and $98.4 \mathrm{~g} / \mathrm{L}$ under 1.0 and $1.5 \mathrm{vvm}$, respectively, and the maximum concentration of D-lactate of $125.1 \mathrm{~g} / \mathrm{L}$ was reached under $2.5 \mathrm{vvm}$, with a yield of $0.91 \mathrm{~g} / \mathrm{g}$ glucose. The accumulation of D-lactate followed a similar trend with cell growth. Cells grew slowly due to the lag phase during the first few hours, and little D-lactate was produced without sufficient cells. During the apparent logarithmic phase, production accumulated rapidly, and productivity was higher than $5 \mathrm{~g} / \mathrm{L} / \mathrm{h}$ (Fig. 6). The highest productivity of $5.96 \mathrm{~g} / \mathrm{L} / \mathrm{h}$ was achieved at $12-16 \mathrm{~h}$ under $1.0 \mathrm{vvm}$. However, the average productivity of $5 \mathrm{~g} / \mathrm{L} / \mathrm{h}$ lasted for as long as $24 \mathrm{~h}$ at $2.5 \mathrm{vvm}$, and $5.85 \mathrm{~g} / \mathrm{L} / \mathrm{h}$ was obtained from $12-16 \mathrm{~h}$, which was very close to the highest productivity under $1.0 \mathrm{vmm}$. The productivity was severely reduced as cells declined and
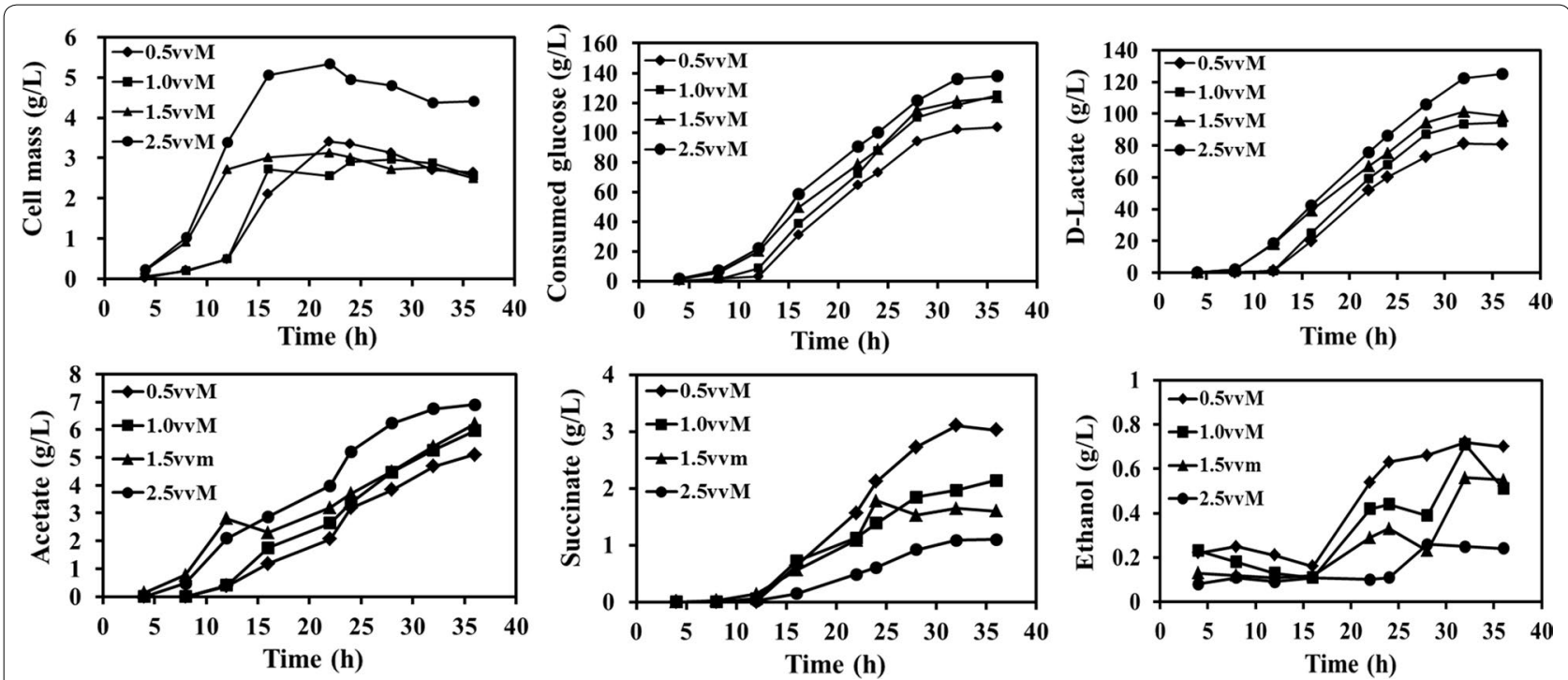

Fig. 5 Cell mass, consumed glucose and primary metabolites in fed-batch fermentation at different aeration rates in a 5 - $L$ bioreactor 


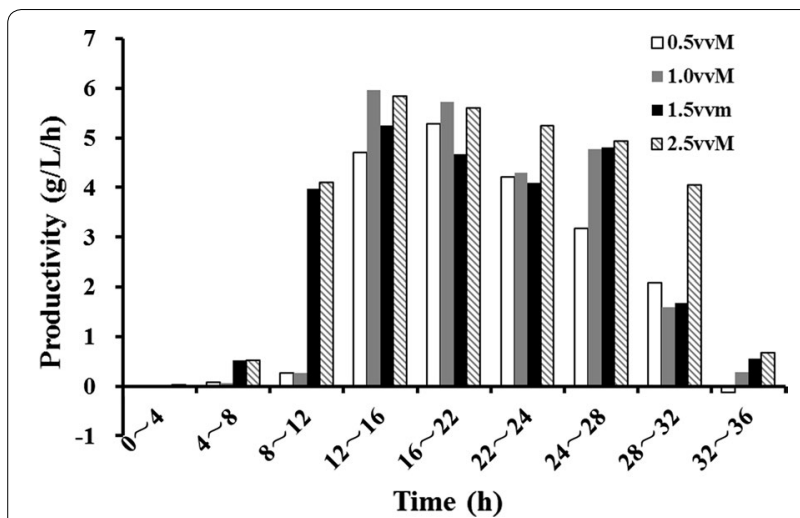

Fig. 6 Productivity of D-lactate at different stages of fed-batch fermentation at different aeration rates

died during the late stationary phase during all of the fedbatch fermentations.

Table 3 summarizes the D-lactate fermentation performances from different carbon sources by different strains. Glucose and glycerol were the main carbon sources used for D-lactate fermentation. Some inexpensive carbon sources, such as sweet potato, corn starch, and monosaccharides from cellulosic hydrolysates, have been used in recent years. Lactobacillus was the most commonly used genus for D-lactate production, and L. coryniformis produced $186.4 \mathrm{~g} / \mathrm{L}$ D-lactate after $60 \mathrm{~h}$ of fermentation from sweet potato with an average productivity of $3.1 \mathrm{~g} / \mathrm{L} / \mathrm{h}$ [29]. However, Lactobacilli usually have two or more lactic dehydrogenases and prefer to racemic lactic acid during fermentation [36, 37]. Escherichia coli has also been genetically modified to produce $\mathrm{D}$-lactate; more than $120 \mathrm{~g} / \mathrm{L}$ was obtained in previous paper [5]. Both Lactobacilli and Escherichia needed nitrogen or carbon dioxide sparging to maintain anaerobic environment for lactate accumulation, which would increase the production costs. There are few studies on D-lactate formation by $K$. pneumoniae with glycerol as the carbon source [7, $12,13]$. To our knowledge, no report regarding D-lactate fermentation from glucose by K. pneumoniae has been published. The high productivity, yield, and optical purity obtained in this study demonstrated that $K$. pneumoniae is an excellent producer of $\mathrm{D}$-lactate from glucose.

As an opportunistic pathogen, K. pneumoniae could pose security risks and limit its industrial applications. The virulence factors of $K$. pneumoniae such as capsule, fimbriae, lipopolysaccharide, adhesins, and siderophores have been identified [38]. And a number of virulence genes which contribute to bacterial pathogenesis such as wabG, fimA, magA, cps, have been systematically analyzed and verified in K. pneumoniae [39]. Genetic

Table 3 Comparison of $\mathrm{D}$-lactate production by different strains using different carbon sources

\begin{tabular}{|c|c|c|c|c|c|c|c|}
\hline Carbon source & Organism & Relevant genotype & $\begin{array}{l}\text { D-Lactate } \\
\text { production } \\
\text { (g/L) }\end{array}$ & Yield $(g / g)$ & $\begin{array}{l}\text { Productivity } \\
\text { (g/L/h) }\end{array}$ & $\begin{array}{l}\text { Optical } \\
\text { purity (\%) }\end{array}$ & References \\
\hline Glucose & K.pneumoniae & $\triangle b u d B \triangle a c k A \triangle a d h E$ & 125.1 & 0.91 & 3.48 & 99.9 & This study \\
\hline Glucose & E. coli & $\begin{array}{l}\triangle a c k \Delta p p s \triangle \text { frdA } \triangle p f l B \triangle d l d \\
\quad \Delta p o x B \triangle a d h E, \text { ldhA }\end{array}$ & 122.8 & 0.84 & 4.32 & NA & {$[5]$} \\
\hline Glucose & $\begin{array}{l}\text { Sporolactobacillus } \\
\text { inulinus }\end{array}$ & pyk & 115.1 & 0.81 & 0.68 & NA & [30] \\
\hline Glucose & $\begin{array}{l}\text { Corynebacterium } \\
\text { glutamicun }\end{array}$ & $\Delta / d h L, I d h A$ & 120 & 0.87 & 4 & 99.9 & {$[31]$} \\
\hline Glucose & $\begin{array}{l}\text { Saccharomyces } \\
\text { cerevisiae }\end{array}$ & $\triangle p d C 1, I d h A$ & 61.5 & 0.61 & 0.85 & 99.9 & {$[6]$} \\
\hline Glycerol & K.pneumoniae & $\Delta d h a T \Delta y q h D, I d h A$ & 142.1 & 0.82 & 2.96 & $\sim 100$ & {$[7]$} \\
\hline Glycerol & K.pneumoniae & $\Delta b u d C, I d h A$ & 68.4 & 0.78 & 1.22 & NA & {$[12]$} \\
\hline Glycerol & K.pneumoniae & - & 59 & 0.47 & 1.13 & NA & [13] \\
\hline Glycerol & E. coli & $\begin{array}{l}\Delta p t a \Delta a d h E \triangle f r d A \triangle d l d p Z S- \\
\text { glpKglpD }\end{array}$ & 32 & 0.80 & 0.54 & 99.9 & [32] \\
\hline Glycerol & E. coli & $\begin{array}{l}\Delta p t a-a c k \triangle p p s \triangle p f l B \triangle d l d \\
\quad \Delta p o x B \triangle a d h E \triangle \operatorname{frd} A, I d h A\end{array}$ & 100.3 & 0.75 & 2.78 & 99.97 & [33] \\
\hline Sucrose & E. coli & $\begin{array}{l}\triangle a d h E \triangle \operatorname{frd} A B C D \triangle p t a \triangle p f B \\
\quad \triangle a l d A \triangle \csc R\end{array}$ & 85 & 0.85 & 1 & 98.3 & [34] \\
\hline Sweet potato & $\begin{array}{l}\text { Lactobacillus } \\
\text { coryniformis }\end{array}$ & - & 186.4 & 0.85 & 3.11 & NA & [29] \\
\hline Corn starch & L.plantarum & $\triangle l d h L:: a m y A$ & 73.2 & 0.73 & 1.53 & 99.6 & {$[35]$} \\
\hline $\begin{array}{l}\text { Glucose, xylose, } \\
\text { arabinose }\end{array}$ & L.plantarum & $\triangle l d h L \triangle x p K 1 \triangle x p K 2$ & 74.2 & 0.78 & 2.06 & 99.5 & {$[8]$} \\
\hline
\end{tabular}


modification is worth trying to eliminate the pathogenic characteristics. Some single gene-deficient mutants have generated in previous studies, the pathogenicity of the mutant strains was reduced dramatically, the growth and the desired product yield were unaffected [40, 41]. What calls special attention is that some new non-pathogenic Klebsiella strains were isolated [42, 43], which will enhance the competitive edge in industrial applications. Some special methods such as cell encapsulation and solar photocatalysis were also evaluated for their potential to diminish the risk of $K$. pneumoniae [44, 45].

The removal of $K$. pneumoniae cells is another obstacle to its commercial applications. K. pneumoniae cells are difficult to separate from fermentation broth because of its capsule and fimbriae, which complicated the downstream processing [46]. Mutant strains devoid of capsule, fimbriae, and lipopolysaccharide could facilitate cell removal by high-speed centrifugation. As a traditional method, centrifugation can remove most of the macromolecules, but the high investment and energy consumption make it to be an unsatisfactory method. Membrane filtration and flocculation are the other two most commonly used methods to remove the cells from fermentation liquors. Although the progress of membrane separation technology has greatly improved its efficiency recently, the membrane fouling and poor material properties still need to be resolved [47]. Flocculation is an important method for the liquid-solid separation process in a number of industrial applications, which have attracted much attention due to its simplicity, and applied to precipitation of different microbial cells in biological industries. Flocculation precipitation is predicted as the most promising method in industrial scale if cheap and effective flocculants are available, some flocculants such as chitosan and polyacrylamide have already been tested for this purpose [48].

The profiles of the by-products are also shown in Fig. 5 . The major by-product was acetate, and accumulation was enhanced with increasing oxygen availability. Here, $6.9 \mathrm{~g} / \mathrm{L}$ acetate accumulated under $2.5 \mathrm{vvm}$, while
$5.11 \mathrm{~g} / \mathrm{L}$ was obtained at $0.5 \mathrm{vvm}$. Succinate and ethanol were also detected under $0.5 \mathrm{vvm}$ at concentrations of 3.03 and $0.7 \mathrm{~g} / \mathrm{L}$, respectively. With increasing oxygen availability, the production of these two by-products decreased; only $1.1 \mathrm{~g} / \mathrm{L}$ succinate and $0.24 \mathrm{~g} / \mathrm{L}$ ethanol were accumulated at $2.5 \mathrm{vvm}$.

\section{Carbon distribution under different aeration rates}

To further understand the metabolism of the mutant strain, the carbon distribution was determined under different aeration rates. As shown in Table 4, the biomass formation increased with aeration: it was 1.67 times higher at $2.5 \mathrm{vvm}$ than that at $0.5 \mathrm{vvm}$. Under higher aeration rates, more D-lactate and biomass generation were the primary reasons for the high carbon recovery. The transformation of glucose to each mol D-lactate generates $1 \mathrm{~mol}$ of NADH; more $\mathrm{D}$-lactate production resulted in greater $\mathrm{NADH}$ formation, and the reducing power required by cell metabolism from oxidative pentose phosphate was reduced; subsequently, $\mathrm{CO}_{2}$ emission from the PP pathway was reduced, which improved carbon recovery. Here, $90.6 \%$ carbon was distributed into D-lactate, and a maximum carbon recovery of $100.2 \%$ was achieved at $2.5 \mathrm{vvm}$. As reported, the organism took up oxygen at a higher rate and converted more glucose to $\mathrm{CO}_{2}$ with decreased oxygen availability [49], which led to greater carbon losses. The total carbon recovery was $<90 \%$, and only approximately $75 \%$ of carbon was used for D-lactate production at $0.5,1.0$, and $1.5 \mathrm{vvm}$. The actual carbon recovery should be lower than calculated in this study, as the glucose requirements for cell growth were reduced with the addition of yeast extract to the medium.

\section{Conclusions}

The effects of single-gene and multiple-gene deletions in $K$. pneumoniae on D-lactate production from glucose via budB, ackA, and $a d h E$ were tested. The triple mutant had the highest capacity for producing D-lactate. The aeration rate played a key role in D-lactate accumulation, and

Table 4 Carbon balance in fed-batch fermentations under different conditions

\begin{tabular}{|c|c|c|c|c|}
\hline \multirow[t]{2}{*}{ Substrates or metabolites } & \multicolumn{4}{|l|}{ Aeration rate } \\
\hline & $0.5 \mathrm{vvm}(\mathrm{mmol})$ & $1.0 \mathrm{vvm}(\mathrm{mmol})$ & $1.5 \mathrm{vvm}(\mathrm{mmol})$ & $2.5 \mathrm{vvm}(\mathrm{mmol})$ \\
\hline Glucose & 3443.3 & 4163.3 & 4113.3 & 4600.0 \\
\hline Biomass & 96.9 & 93.8 & 91.7 & 161.5 \\
\hline D-Lactate & 2696.3 & 3153.3 & 3280.0 & 4170.0 \\
\hline Acetate & 170.3 & 198.7 & 206.7 & 230.0 \\
\hline Succinate & 102.7 & 72.5 & 54.2 & 37.3 \\
\hline Ethanol & 30.4 & 22.2 & 23.9 & 10.4 \\
\hline Lactate recovery (\%) & 78.3 & 75.7 & 79.7 & 90.6 \\
\hline Carbon recovery (\%) & 89.9 & 85.1 & 88.9 & 100.2 \\
\hline
\end{tabular}


$125.1 \mathrm{~g} / \mathrm{L}$ of D-lactate with a yield of $0.91 \mathrm{~g} / \mathrm{g}$ glucose in $36 \mathrm{~h}$ was produced by the triple mutant at $2.5 \mathrm{vvm}$. This study demonstrated that K. pneumoniae is an excellent producer of D-lactate from glucose and also showed the feasibility of producing D-lactate from pentose sugars, such as xylose and arabinose.

\section{Authors' contributions}

$M X$ and GZ developed the idea for the study, and helped to revise the manuscript. XF designed the research, did the literature review and prepared the manuscript. $X F, L J, X H, X L, Z Z$, and $H L$ did experiments, plasmid construction, strain cultivation, fed-batch fermentation and product detection. All authors read and approved the final manuscript.

\section{Author details}

${ }^{1}$ CAS Key Laboratory of Biobased Materials, Qingdao Institute of Bioenergy and Bioprocess Technology, Chinese Academy of Sciences, Qingdao 266101, China. ${ }^{2}$ CAS Key Laboratory of Renewable Energy, Guangzhou Institute of Energy Conversion, Chinese Academy of Sciences, Guangzhou 510640, China. ${ }^{3}$ University of Chinese Academy of Sciences, Beijing 100049, China.

\section{Acknowledgements}

We acknowledge Dr. Roy Curtiss III (Arizona State University) for strain X7213 and PRE112.

\section{Competing interests}

The authors declare that they have no competing interests.

\section{Availability of data and materials}

The datasets used and/or analysed during the current study are available from the corresponding author on reasonable request.

\section{Consent for publication}

Not applicable.

\section{Ethics approval and consent to participate}

Not applicable.

\section{Funding}

This research was financially supported by National Natural Science Foundation of China (31670089), CAS Key Program (ZDRW-ZS-2016-3M), Taishan Scholars Climbing Program of Shandong (No. TSPD20150210), CAS Key Laboratory of Renewable Energy, Guangzhou Institute of Energy Conversion (No. Y707kb1001), and CAS Key Laboratory of Bio-based Materials (No. KLBM 2016008).

\section{Publisher's Note}

Springer Nature remains neutral with regard to jurisdictional claims in published maps and institutional affiliations.

Received: 16 September 2017 Accepted: 12 November 2017

Published online: 21 November 2017

\section{References}

1. Garlotta D. A literature review of poly(lactic acid). J Polym Environ. 2011;9:63-84.

2. Fukushima K, Chang Y, Kimura Y. Enhanced stereocomplex formation of poly(L-lactic acid) and poly(D-lactic acid) in the presence of stereoblock poly(lactic acid). Macromol Biosci. 2007;7:829-35.

3. Nguyen CM, Kim JS, Nguyen TN, Kim SK, Choi GJ, Choi YH, Jang KS, Kim J. Production of L- and D-lactic acid from waste Curcuma longa biomass through simultaneous saccharification and cofermentation. Bioresour Technol. 2013;146:35-43.

4. Zhao B, Wang L, Li F, Hua D, Ma C, Ma Y, Xu P. Kinetics of D-lactic acid production by Sporolactobacillus sp. strain CASD using repeated batch fermentation. Bioresour Technol. 2010;101:6499-505.
5. Zhou L, Niu D, Tian K, Chen X, Prior BA, Shen W, Shi G, Singh S, Wang Z. Genetically switched D-lactate production in Escherichia coli. Metab Eng. 2012;14:560-8.

6. Ishida N, Suzuki T, Tokuhiro K, Nagamori E, Onishi T, Saitoh S, Kitamoto K, Takahashi H. D-Lactic acid production by metabolically engineered Saccharomyces cerevisiae. J Biosci Bioeng. 2006;101:172-7.

7. Feng $X$, Ding $Y$, Xian $M, X u$ X, Zhang R, Zhao G. Production of optically pure $D$-lactate from glycerol by engineered Klebsiella pneumoniae strain. Bioresour Technol. 2014;172:269-75.

8. Yoshida S, Okano K, Tanaka T, Ogino C, Kondo A. Homo-D-lactic acid production from mixed sugars using xylose-assimilating operon-integrated Lactobacillus plantarum. Appl Microbiol Biotechnol. 2011;92:67-76.

9. Zhou L, Zuo Z, Chen X, Niu D, Tian K, Prior BA, Shen W, Shi G, Singh S, Wang Z. Evaluation of genetic manipulation strategies on D-lactate production by Escherichia coli. Curr Microbiol. 2011;62:981-9.

10. Li Y, Wang X, Ge X, Tan P. High production of 3-hydroxypropionic acid in Klebsiella pneumoniae by systematic optimization of glycerol metabolism. Sci Rep. 2016;6:26932.

11. Durgapal M, Kumar V, Yang TH, Lee HJ, Seung D, Park S. Production of 1,3-propanediol from glycerol using the newly isolated Klebsiella pneumoniae J2B. Bioresour Technol. 2014;159:223-31.

12. Wang F, Meng Q. Effects of budC gene knockout and IdhA overexpression on D-lactic acid production by Klebsiella pneumoniae. J Beijing Univ Chem Technol (Natl Sci). 2010;39:84-9.

13. Rossi DM, de Souza EA, Ayub MA. Biodiesel residual glycerol metabolism by Klebsiella pneumoniae: pool of metabolites under anaerobiosis and oxygen limitation as a function of feeding rates. Appl Biochem Biotechnol. 2013;169:1952-64.

14. Roland K, Curtiss R, Sizemore D. Construction and evaluation of a $\triangle$ cya $\triangle c r p$ Salmonella typhimurium strain expressing avian pathogenic Escherichia coli O78 LPS as a vaccine to prevent airsacculitis in chickens. Avian Dis. 1999;43:429-41.

15. Edwards RA, Keller LH, Schifferli DM. Improved allelic exchange vectors and their use to analyze 987P fimbria gene expression. Gene. 1998;207:149-57.

16. Livak KJ, Schmittgen TD. Analysis of relative gene expression data using real-time quantitative PCR and the $2^{-\triangle \Delta C T}$ method. Methods. 2001;25:402-8

17. Zou H, Wu Z, Xian M, Liu H, Cheng T, Cao Y. Not only osmoprotectant: betaine increased lactate dehydrogenase activity and L-lactate production in Lactobacilli. Bioresour Technol. 2013;148:591-5.

18. Huang Y, Li Z, Shimizu K, Ye Q. Co-production of 3-hydroxypropionic acid and 1,3-propanediol by Klebseilla pneumoniae expressing aldH under microaerobic conditions. Bioresour Technol. 2013;128:505-12.

19. Cui Y, Zhou J, Gao L, Zhu C, Jiang X, Fu S, Gong H. Utilization of excess $\mathrm{NADH}$ in 2,3-butanediol-deficient Klebsiella pneumoniae for 1,3-propanediol production. J Appl Microbiol. 2014;117:690-8.

20. Lin J, Zhang Y, Xu D, Xiang G, Jia Z, Fu S, Gong H. Deletion of poxB, pta, and ackA improves 1,3-propanediol production by Klebsiella pneumoniae. Appl Microbiol Biotechnol. 2016;100:2775-84.

21. Kang Z, Geng Y, Xia Y, Kang J, Qi Q. Engineering Escherichia coli for an efficient aerobic fermentation platform. J Biotechnol. 2009;144:58-63.

22. Liu M, Yao L, Xian M, Ding YM, Liu HZ, Zhao G. Deletion of arCA increased the production of acetyl-CoA-derived chemicals in recombinant Escherichia coli. Biotechnol Lett. 2016;38:97-101.

23. Lee S, Oh B, Park JM, Yu A, Heo S, Hong W, Seo J, Kin CH. Optimized production of 2,3-butanediol by a lactate dehydrogenase-deficient mutant of Klebsiella pneumoniae. Biotechnol Bioprocess E. 2013;18:1210-5.

24. Kim B, Lee S, Yang J, Jeong D, Shin SH, Kook JH, Yang K, Lee J. The influence of budA deletion on glucose metabolism related in 2,3-butanediol production by Klebsiella pneumoniae. Enzyme Microb Tech. 2016:73-74:1-8.

25. Zhang G, Yang G, Wang X, Guo Q, Li Y, Li J. Influence of blocking of 2,3-butanediol pathway on glycerol metabolism for 1,3-propanediol production by Klebsiella oxytoca. Appl Biochem Biotechnol. 2012;168:116-28.

26. Jantama K, Polyiam P, Khunnonkwao O, Chan S, Sangproo M, Khor K, Jantama SS, Kanchanatawee S. Efficient reduction of the formation of by-products and improvement of production yield of 2,3-butanediol by a combined deletion of alcohol dehydrogenase, acetate kinase- phosphotransacetylase, and lactate dehydrogenase genes in metabolically 
engineered Klebsiella oxytoca in mineral salts medium. Metab Eng. 2015;30:16-26.

27. Bothast RJ, Saha BC, Flosenzier AV, Ingram LO. Fermentation of L-arabinose, D-xylose and D-glucose by ethanologenic recombinant Klebsiella oxytoca strain P2. Biotechnol Lett. 1994;16:401-6.

28. Gírio FM, Fonseca C, Carvalheiro F, Duarte LC, Marques S, BogelŁukasik R. Hemicelluloses for fuel ethanol: a review. Bioresour Technol. 2010;101:4775-800.

29. Nguyen CM, Choi GJ, Choi YH, Jang KS, Kim J. D- and L-lactic acid production from fresh sweet potato through simultaneous saccharification and fermentation. Biochem Eng J. 2013:81:40-6.

30. Zheng L, XuT, Bai Z, He B. $M n^{2+} / \mathrm{Mg}^{2+}$-dependent pyruvate kinase from a D-lactic acid-producing bacterium Sporolactobacillus inulinus: characterization of a novel $\mathrm{Mn}^{2+}$-mediated allosterically regulated enzyme. Appl Microbiol Biotechnol. 2014;98:1583-93.

31. Okino S, Suda M, Fujikura K, Inui M, Yukawa H. Production of D-lactic acid by Corynebacterium glutamicum under oxygen deprivation. Appl Microbiol Biotechnol. 2008:78:449-54

32. Mazumdar S, Clomburg JM, Gonzalez R. Escherichia coli strains engineered for homofermentative production of D-lactic acid from glycerol. Appl Environ Microbiol. 2010;76:4327-36.

33. Chen X, Tian K, Niu D, Shen W, Algasan G, Singh S, Wang Z. Efficient bioconversion of crude glycerol from biodiesel to optically pure D-lactate by metabolically engineered Escherichia coli. Green Chem. 2014;16:342-50.

34. Wang Y, Tian T, Zhao J, Wang J, Yan T, Xu L, Liu Z, Garza E, Iverson A, Manow R, Finan C, Zhou S. Homofermentative production of D-lactic acid from sucrose by a metabolically engineered Escherichia coli. Biotechnol Lett. 2012;34:2069-75

35. Okano K, Zhang Q, Shinkawa S, Yoshida S, Tanaka T, Fukuda H, Kondo A. Efficient production of optically pure D-lactic acid from ran corn starch by using a genetically modified L-lactate dehydrogenase gene-deficient and a-amylase secreting Lactobacillus plantarum strain. Appl Environ Microbiol. 2009:75:462-7.

36. Gasser F. Electrophoretic characterization of lactic dehydrogenases in the genus Lactocacillus. J Gen Microbiol. 1970;62:223-39.

37. Dennis D, Kaplan NO. D- and L-lactic acid dehydrogenases in Lactobacillus plantarum. J Biol Chem. 1960;235:810-8.
38. Podschun R, Ullmann U. Klebsiella spp. as an nosocomial pathogens: epidemiology, taxonomy, typing methods, and pathogenicity factors. Clin Microbiol Rev. 1998;11:589-603.

39. Brisse S, Fevre C, Passet V, Issenhuth-Jeanjean S, Tournebize R, Diancourt L, Grimont P. Virulent clones of Klebsiella pneumoniae: identification and evolutionary scenario based on genomic and phenotypic characterization. PLoS ONE. 2009:4:e4982.

40. Guo NN, Zheng ZM, Mai YL, Liu HJ, Liu DH. Consequences of cps mutation of Klebsiella pneumoniae on 1,3-propanediol fermentation. Appl Microbiol Biotechnol. 2010;86:701-7.

41. Huynh DTN, Kim AY, Seol IH, Juang S, Lim MC, Lee JA, Jo MR, Choi SJ, Kim B, Lee J, Kim W, Kim YR. Inactivation of the virulence factors from 2,3-butanediol-producing Klebsiella pneumoniae. Appl Microbiol Biotechnol. 2015;99:9427-38.

42. Souza EAD, Rossi DM, Ayub MAZ. Bioconversion of residual glycerol from biodiesel synthesis into 1,3-propanediol using immobilized cells of Klebsiella pneumoniae BLH-1. Renew Energ. 2014;72:253-7.

43. Yang G, Tian JS, Li JL. Fermentation of 1,3-propanediol by a lactate deficient mutant Klebsiella oxytoca under microaerobic conditions. Appl Microbiol Biotechnol. 2007;73:1017-24.

44. Zhao Y, Chen G, Yao S. Microbial production of 1,3-propanediol from glycerol by encapsulated Klebsiella pneumoniae. Biochem Eng J. 2006:32:93-9.

45. Venieri D, Gounaki I, Bikouvaraki M, Binas V, Zachopoulos A, Kiriakidis G, Mantzavinos D. Solar photocatalysis as disinfection technique: inactivation of Klebsiella pneumoniae in sewage and investigation of changes in antibiotic resistance profile. J Environ Manage. 2016;195:140-7.

46. Kumar V, Park S. Potential and limitations of Klebsiella pneumoniae as a microbial cell factory utilizing glycerol as the carbon source. Biotechnol Adv. 2017. https://doi.org/10.1016/j.biotechadv.2017.10.004.

47. Meng FG, Chae SR, Drews A, Kraume M, Shin HS, Yang FL. Recent advances in membrane bioreactors (MBRs): membrane fouling and membrane material. Water Res. 2009;43:1489-512.

48. Hao J, Xu F, Liu HJ, Liu DH. Downstream processing of 1,3-propanediol fermentation broth. J Chem Technol Biotechnol. 2006;81:102-8.

49. Harrison DEF, Pirt SJ. The influence of dissolved oxygen concentration on the respiration and glucose metabolism of Klebsiella aerogenes during growth. J Gen Microbiol. 1967;46:193-211.

\section{Submit your next manuscript to BioMed Central and we will help you at every step:}

- We accept pre-submission inquiries

- Our selector tool helps you to find the most relevant journal

- We provide round the clock customer support

- Convenient online submission

- Thorough peer review

- Inclusion in PubMed and all major indexing services

- Maximum visibility for your research

Submit your manuscript at www.biomedcentral.com/submit
BioMed Central 